\title{
Analisis Faktor-Faktor yang Mempengaruhi Pengembangan Karir Personil Polri pada Satuan Kerja Biro Operasi Polda Aceh
}

\author{
Yudhi YULIZAR \\ Fakultas Ekonomi, Universitas Serambi Mekkah, \\ Jalan Batoh, Lueng Bata, Kota Banda Aceh, Provinsi Aceh, Indonesia \\ yudhiyulizar@gmail.com \\ SARBOINI \\ Fakultas Ekonomi, Universitas Serambi Mekkah, \\ Jalan Batoh, Lueng Bata, Kota Banda Aceh, Provinsi Aceh, Indonesia \\ sarboinise@serambimekkah.ac.id \\ MARIATI * \\ Fakultas Ekonomi, Universitas Serambi Mekkah, \\ Jalan Batoh, Lueng Bata, Kota Banda Aceh, Provinsi Aceh, Indonesia \\ mariati@serambimekkah.ac.id
}

\section{Article's history:}

Received 15 February 2020; Received in revised form 13 July 2020; Accepted 17 August, 2020; Published 30 August 2020. All rights reserved to the Lembaga Otonom Lembaga Informasi dan Riset Indonesia (KITA INFO dan RISET).

\section{Suggested citation:}

Yulizar, Y., Sarbioni, Mariati. 2020. Analisis Faktor-Faktor yang Mempengaruhi Pengembangan Karir Personil Polri pada Satuan Kerja Biro Operasi Polda Aceh. JEMSI (Jurnal Ekonomi, Manajemen, dan Akuntansi), Volume 6 (2): 59-70. DOI: https://doi.org/10.35870/jemsi.v6i1.339.

\section{ABSTRAK:}

Penelitian ini bertujuan untuk mengetahui analisis faktor-faktor yang mempengaruhi pengembangan karier personil Polri pada Satuan Kerja Biro Operasi Polda Aceh. Populasi penelitian ini berjumlah 64 orang Personil Polri, dan model penarikan sampel menggunakan sensus sehingga diperoleh 64 orang pegawai sebagai sampel. Metode penelitian menggunakan analisis regresi linier berganda. Hasil penelitian menunjukkan bahwa pengalaman kerja dan pelatihan secara simultan berpengaruh signifikan terhadap pengembangan karier personil Polri pada Satuan Kerja Biro Operasi Polda Aceh, dengan nilai Fhitung $>$ Ftabel $(40,079>3,150)$. Sedangkan secara parsial pengalaman kerja dan pelatihan berpengaruh signifikan terhadap pengembangan karier personil Polri pada Satuan Kerja Biro Operasi Polda Aceh, dengan nilai thitung >ttabel $(2,562$ dan 5,241>1,998). Nilai koefisien korelasi (R) menunjukkan bahwa hubungan (korelasi) antara variabel bebas dengan variabel terikat sebesar $75,4 \%$, artinya pengembangan karir Personil Polri pada Satuan Kerja Biro Operasi Polda Aceh mempunyai hubungan yang cukup erat dan positif dengan pengalaman kerja (X1) dan pelatihan (X2). Sedangkan nilai korelasi determinasi (R2) sebesar 0,568 menunjukkan bahwa pengaruh pengalaman kerja dan pelatihan terhadap pengembangan karir Personil Polri pada Satuan Kerja Biro Operasi Polda Aceh sebesar 56,8\% dan sisanya sebesar 43,2\% dijelaskan oleh variabel lain diluar dari pada penelitian ini misalnya pendidikan, prestasi kerja, motivasi kerja, disiplin kerja, kompensasi dan lain-lain. Berdasarkan hasil analisis regresi linier berganda, maka dapat diketahui bahwa dari kedua variabel yang diteliti, ternyata variabel pelatihan (X2) yang mempunyai pengaruh paling dominan terhadap pengembangan karir Personil Polri pada Satuan Kerja Biro Operasi Polda Aceh, dengan nilai koefesien sebesar 0,556 dan selanjutnya diikuti oleh variabel pengalaman kerja (X2) mempunyai nilai koefisien sebesar 0,272 .

Kata Kunci: Pengalaman Kerja; Pelatihan; Pengembangan Karir.

JEL Classification: C93; M53; 015. 


\section{PENDAHULUAN}

Pengembangan karir adalah proses mengidentifikasi potensi karir pegawai, serta menerapkan cara-cara yang tepat untuk mengembangkan potensi tersebut. Handoko (2008:130-131) menjelaskan bahwa implimentasi rencana-rencana karir memerlukan pengembangan karir. Pengembangan karir merupakan upaya-upaya pribadi seorang karyawan untuk mencapai suatu rencana karir. Sejalan dengan hal tersebut, Siagian (2008:215) mengatakan bahwa betapapun baiknya suatu rencana karir yang telah dibuat oleh seorang pekerja disertai oleh suatu tujuan karir yang wajar dan realistik, rencana tersebut tidak akan menjadi kenyataan tanpa adanya pengembangan karir yang sistematik dan programatik.

Pengembangan karir sangat penting untuk suatu instansi, karena karir merupakan kebutuhan yang harus terus ditumbuhkan dalam diri seorang tenaga kerja, sehingga mampu mendorong kemauan kerjanya. Pengembangan karir harus dilakukan melalui penumbuhan kebutuhan karir tenaga kerja, menciptakan kondisi dan kesempatan pengembangan karir serta melakukan penyesuaian antara keduanya. Kebijakan organisasi, latar belakang pendidikan, pelatihan, pengalaman kerja, kesetiaan pada organisasi, dan keluwesan bergaul dan hubungan antar manusia ini sangat berpengaruh pada pencapaian karir karyawan. Dalam penelitian ini ada beberapa faktor yang dapat mempengaruhi pengembangan karir personil Polri pada Satuan Kerja Biro Operasi Polda Aceh, yaitu pengalaman kerja dan pelatihan.

Dengan adanya pengalaman kerja, pasti pegawai akan merasa dihargai, diperhatikan, dibutuhkan dan diakui kemampuan kerjanya oleh Satuan Kerja Biro Operasi Polda Aceh sehingga mereka akan menghasilkan keluaran yang tinggi serta akan mempertinggi kesetiaan pada instansi tersebut. Oleh karena itu, pimpinan harus menyadari pentingnya pengalaman kerja untuk meningkatkan pengembangan karir yang harus dipertimbangkan secara objektif. Jika pimpinan telah menyadari dan mempertimbangkan, maka instansi tersebut akan terhindar dari masalah-masalah yang menghambat peningkatan keluaran dan dapat merugikan instansi seperti: ketidakpuasan pegawai, adanya keluhan, tidak adanya semangat kerja, menurunnya disiplin kerja, tingkat absensi yang tinggi atau bahkan masalah-masalah pemogokan kerja. Untuk dapat memutuskan imbalan yang sepenuhnya diberikan kepada seorang pegawai atas hasil kerjanya, maka instansi/lembaga harus memiliki suatu sistem balas jasa yang tepat.

Pelatihan selain sebagai sarana untuk meningkatkan kemampuan dan keterampilan pegawai dalam meningkatkan pengembangan karir, juga merupakan sarana yang penting bagi pihak manajemen dalam menerapkan strategi organisasi. Meskipun pelatihan tenaga kerja memerlukan biaya yang tidak sedikit, tetapi pelatihan harus tetap dilaksanakan, karena pendidikan pelatihan tersebut mempunyai manfaat yang sangat besar baik bagi organisasi maupun bagi pegawai. Manfaat bagi pegawai itu sendiri adalah mereka dapat mengembangkan sikap, perilaku, keterampilan dan pengetahuaan tentang pekerjaannya. Hal ini dapat meningkatkan kinerja para pegawainya, sehingga dapat lebih menunjang tercapainya tujuan instansi/lembaga secara efektif dan efesien.

Sesuai dengan UU No. 2 Tahun 2002 tentang Kepolisian Negara Republik Indonesia, tercantum pada Pasal 13 di mana tugas pokok POLRI adalah memelihara keamanan dan ketertiban masyarakat, menegakkan hukum serta sebagai pelindung, pengayom dan pelayan masyarakat. Dengan adanya undang- undang ini, Satuan Kerja Biro Operasi Polda Aceh, yang merupakan bagian dari organisasi POLRI harus bisa memberikan pelayanan yang terbaik bagi masyarakat Aceh untuk menciptakan keamanan, keselamatan, ketertiban dan kelancaran diseluruh wilayah hukum Polda Aceh. Terlebih pada saat sekarang era pasca reformasi, dimana masyarakat Kota Banda Aceh semakin kritis dan menuntut Satuan Kerja Biro Operasi Polda Aceh agar lebih profesional dalam melayani masyarakat.

Dalam melaksanakan tugas dan tanggung jawab tersebut, maka sangat dibutuhkan suatu pengembangan karir yang produktif sehingga bisa menjalankan tujuan dari organisasi POLRI ini pada umumnya. Untuk menciptakan pengembangan karir yang produktif ini maka diperlukan pengalaman kerja dan pelatihan pada Satuan

Kerja Biro Operasi Polda Aceh dalam melayani masyarakat di lingkungan kerjanya. Satuan Kerja Biro Operasi Polda Aceh mendukung lembaga induknya dalam menjalankan tugas pokoknya untuk melayani masyarakat. 


\section{TINJAUAN KEPUSTAKAAN}

\section{Pengembangan Karir}

Menurut Mangkunegara (2011:73) pengembangan karir adalah aktivitas kepegawaian yang membantu pegawai-pegawai merencanakan karir masa depan mereka diperusahaan agar perusahaan dan pegawai yang bersangkutan dapat mengembangkan dari secara maksimum. Gomes (2007:95) menyatakan bahwa karir adalah suatu rangkaian kegiatan kerja yang terpisahkan tetapi berkaitan, yang memberikan keseimbangan, ketentraman, dan arti dalam hidup seseorang.

Selanjutnya menurut Raymond (2010:523) pengembangan karir adalah sebagai perolehan pengetahuan, ketrampilan, dan perilaku yang meningkatkan kemampuan pegawai untuk memenuhi perubahan persyaratan pekerjaan serta tuntutan klien dan pelanggan. Sementara itu menurut Soeprihantoro (2009:42) menyatakan bahwa karir adalah perkembangan para karyawan secara individu dalam jenjang jabatan atau kepangkatan yang dapat dicapai selama masa kerja dalam suatu organisasi atau perusahaan.

Sedangkan Rivai (2009:290) mengatakan bahwa: "Pengembangan karir adalah proses peningkatan kemampuan kinerja individu yang dicapai dalam rangka mencapai karir yang diinginkan". Rivai dan Sagala (2009:65) menyatakan bahwa pengembangan karir adalah proses peningkatan kemampuan kerja individu yang dicapai dalam rangka mencapai karir yang diinginkan. Selanjutnya Dessler (2010:5) menyatakan pengembangan karir adalah sebagai serangkaian aktivitas sepanjang hidup yang berkontribusi pada eksplorasi, pemantapan, keberhasilan, dan pencapaian karir seseorang.

\section{Faktor-Faktor Yang Mempengaruhi Pengembangan Karir}

Menurut Siagian (2008:215) adapun faktor yang dapat mempengaruhi pengembangan karir seorang pegawai adalah:

1. Prestasi Kerja

Faktor yang paling penting untuk meningkatkan dan mengembangkan karir seorang pegawai adalah pada prestasi kerjanya dalam melakukan tugas yang dipercayakan kepadanya. Tanpa prestasi kerja yang memuaskan, sukar bagi seorang pekerja untuk diusulkan oleh atasannya agar dipertimbangkan untuk dipromosikan ke pekerjaan atau jabatan yang lebih tinggi di masa depan.

2. Pengenalan oleh pihak lain

Adalah berbagai pihak yang berwenang memutuskan layak tidaknya seseorang dipromosikan seperti atasan langsung danpimpinan bagian kepegawaian yang mengetahui kemampuan dan prestasi kerja seorang pegawai.

3. Kesetiaan pada organisasi

Merupakan dedikasi seorang pegawai yang ingin terus berkarya dalam organisasi tempatnya bekerja untuk jangka waktu yang lama.

4. Pembimbing dan sponsor

Pembimbing adalah orang yang memberikan nasehat-nasehat atau saran-saran kepada pegawai dalam upaya mengembangkan karirnya. Sedangkan sponsor adalah seseorang didalam institusi pendidikan yang dapat menciptakan kesempatan bagi pegawai untuk mengembangkan karirnya.

5. Dukungan para bawahan

Merupakan dukungan yang diberikan para bawahan dalam bentuk mensukseskan tugas manajer yang bersangkutan.

6. Kesempatan untuk bertumbuh

Merupakan kesempatan yang diberikan kepada pegwai untuk meningkatkan kemampuannya, baik melalui pelatihan-pelatihan, kursus, dan juga melanjutkan jenjang pendidikannya.

7. Pengunduran diri

Merupakan keputusan seorang pegawai untuk berhenti bekerja dan beralih ke institusi pendidikan lain yang memberikan kesempatan lebih besar untuk mengembangkan karir.

Sedangkan Menurut Tohardi (2007:281), ada lima faktor yang akan mempengaruhi mulus tidaknya karir seseorang pegawai. Untuk itulah kelima faktor tersebut harus dikelola oleh karyawan dengan baik, bila karyawan atau pekerja yang bersangkutan ingin meraih karir yang lebih tinggi. Kelima faktor tersebut yaitu:

1. Sikap Atasan, Rekan Sekerja dan Bawahan 
Bila seorang pegawai ingin meniti karirnya dengan mulus maka selain membenahi diri dengan segudang prestasi, juga perlu memback-up diri dengan perangai, tingkah laku atau moral yang baik.

2. Pengalaman

Pengalaman dalam konteks ini dapat berkaitan dengan tingkat golongan (senioritas) seseorang pegawai, walaupun hal ini masih tetap diperdebatkan.

3. Pendidikan

Faktor pendidikan biasanya menjadi syarat untuk duduk di sebuah jabatan, misalnya syarat untuk menjadi seorang dosen maka minimal harus berpendidikan sarjana.

4. Prestasi

Prestasi dapat saja terjadi dari akumulasi dari pengalaman, pendidikan dan lingkungan kerja yang biak. Namun prestasi yang baik tentunya merupakan usaha yang kuat dari dalam diri seseorang, walaupun karena keterbatasan pendidikan, pengalaman dan dukungan rekan-rekan sekerja.

5. Faktor Nasib

Adanya faktor nasib yang turut mempengaruhi harus diyakini ada, karena dalam kenyataan ada yang berprestasi tetapi tidak pernah mendapat peluang untuk dipromosikan.

\section{Pengalaman Kerja}

Pengalaman kerja adalah suatu dasar/acuan seorang pegawai dapat menempatkan diri secara tepat kondisi, berani mengambil resiko, mampu menghadapi tantangan dengan penuh tanggung jawab serta mampu berkomunikasi dengan baik terhadap berbagai pihak untuk tetap menjaga produktivitas, kinerja dan menghasilkan individu yang kompeten dalam bidangnya (Sutrisno, 2009:158). Pengalaman kerja adalah lamanya seseorang melaksanakan frekuensi dan jenis tugas sesuai dengan kemampuannya (Syukur, 2007:74). Menurut Suwatno (2009:129) pengalaman kerja adalah yaitu pengalaman seseorang tenaga kerja untuk melakukan pekerjaan tertentu. Menurut Hariandja (2007:120) pengalaman kerja adalah suatu pekerjaan atau jabatan yang pernah diduduki sebelumya selama kurun waktu tertentu. Pengalaman kerja adalah sebagai suatu ukuran tentang lama waktu atau masa kerjanya yang telah ditempuh seseorang dalam memahami tugas-tugas suatu pekerjaan dan telah melaksanakannya dengan baik (Foster, 2009:40).

Pengalaman kerja menurut Manulang dalam Ismanto (2008:24) adalah proses pembentukan pengetahuan atau keterampilan tentang metode suatu pekerjaan karena keterlibatan karyawan tersebut dalam pelaksanaan tugas pekerjaan. Sedangkan menurut Ranupandojo dalam Ismanto (2008:24), pengalaman kerja adalah ukuran tentang lama waktu atau masa kerja yang telah ditempuh seseorang, dapat memahami tugas-tugas suatu pekerjaan dan telah melaksanakan dengan baik. Menurut Oemar Hamalik (2008:29) pengalaman adalah sumber pengetahuan dan pengalaman diperoleh karena adanya interaksi antara individu dengan lingkungannya.

Sedangkan menurut Syukur (2007:83) menyatakan bahwa cara yang dapat dilaksanakan untuk memperoleh pengalaman kerja adalah:

1. Pendidikan

Berdasarkan pendidikan yang dilaksanakan oleh seseorang, maka orang tersebut dapat memperoleh pengalaman kerja yang lebih banyak dari sebelumnya.

2. Pelaksanaan tugas

Melalui pelaksanaan tugas sesuai dengan kemampuannya, maka seseorang akan semakin banyak memperoleh pangalaman kerja.

3. Media informasi

Pemanfaatan berbagai media informasi, akan mendukung seseorang untuk memperoleh pengalaman kerja yang lebih banyak.

4. Penataran

Melalui kegiatan penataran dan sejenisnya, maka seseorang akan memperoleh pengalamanan kerja untuk diterapkan sesuai dengan kemampuannya.

5. Pergaulan

Melalui pergaulan dalam kehidupan sehari-hari, maka seseorang akan memperoleh pengalaman kerja untuk diterapkan sesuai dengan kemampuannya. 


\section{Pengamatan}

Selama seseorang mengadakan pengamatan terhadap suatu kegiatan tertentu, maka orang tersebut akan dapat memperoleh pengalaman kerja yang lebih baik sesuai dengan taraf kemampuannya.

\section{Pelatihan}

Menurut Hasibuan (2013:76) pelatihan adalah bagian pendidikan yang menyangkut proses belajar untuk memperoleh dan meningkatkan keterampilan diluar sistem pendidikan yang berlaku, dalam waktu yang relatif singkat dan metode yang lebih mengutamakan praktik dari pada teori. Menurut Pramudyo (2007:16) pelatihan adalah proses pembelajaran yang dirancang untuk mengubah kinerja orang dalam melakukan pekerjaannya. Menurut Hardjana (2009:12) pelatihan adalah kegiatan yang dirancang untuk meningkatkan kinerja pekerja dalam pekerjaan yang diserahkan kepada mereka. Ivancevich dalam Marwansyah (2010:154), mengatakan bahwa:

"Pelatihan adalah proses sistematis untuk mengubah perilaku karyawa, yang diarahkan untuk mencapai tujuan-tujuan organisasi. Pelatihan terkait dengan keterampilan dan kemampuan pekerjaan saat ini. Orientasinya adalah saat ini membantu karyawan mengawasi keterampilan dan kemampuan spesifik agar berhasil dalam pekerjaan". Pelatihan adalah proses membantu pegawai memperoleh efektifitas dalam pekerjaan sekarang atau yang akan datang melalui pengembangan kebiasaan, pikiran dan tindakan, kecakapan, pengetahuan dan sikap. (Edwin B. Flippo dalam Sedarmayanti, 2010:164). Menurut Rivai (2009:211) pelatihan merupakan bagian pendidikan yang menyangkut proses belajar untuk memperoleh dan meningkatkan keterampilan diluar sistem pendidikan yang berlaku dalam waktu relatif singkat dengan metode yang lebih mengutamakan pada praktek dari pada teori. Sedangkan pengertian pelatihan menurut Handoko (2008:104) pelatihan merupakan usaha untuk memperbaiki penguasaan berbagai keterampilan dan teknik pelaksanaan kerja tertentu, terinci dan rutin.

Selanjutnya Dessler (2010:280) mengatakan bahwa: "Pelatihan merupakan proses mengajar ketrampilan yang dibutuhkan pegawai untuk melakukan pekerjaannya". Pelatihan menurut Mangkuprawira (2008:135) menjelaskan bahwa pelatihan adalah sebuah proses mengajarkan pengetahuan dan keahlian tertentu serta sikap agar pegawai semakin terampil dan mampu melaksanakan tanggung jawab dengan semakin baik, sesuyai dengan standar. Menurut Marthis dan Jacson (2009:301) pelatihan adalah proses dimana orang mendapatkan kapabilitas untuk membantu pencapaian tujuan.

Sedangkan menurut Sastrohardiwiryo (2009:199) pelatihan merupakan proses membantu para tenaga kerja untuk memperoleh efektifitas dalam perkerjaan mereka yang sekarang atau yang akan datang melalui pengembangan kebiasaan tentang pikiran, tindakan, kecakapan, pengetahuan, dan sikap yang layak. Pelatihan (training) merupakan proses pembelajaran yang melibatkan perolehan keahlian, konsep, peraturan, atau sikap untuk meningkatkan kinerja tenaga kerja (Simamora, 2008:273).

\section{METODE PENELITIAN}

\section{Kerangka Penelitian}

Menurut Sugiyono (2014:60) mengemukakan bahwa kerangka berpikir merupakan model konseptual tentang bagaimana teori berhubungan dengan berbagai faktor yang telah diidentifikasi dan kerangka berpikir adalah sebuah pemahaman yang melandasi pemahaman yang lainnya, sebuah pemahaman yang paling mendasar dan menjadi pondasi bagi setiap pemikiran atau suatu bentuk proses dari keseluruhan dari penelitian yang akan dilakukan. Secara skematis, kerangka konseptual dalam penelitian ini dapat dilihat pada Gambar dibawah.

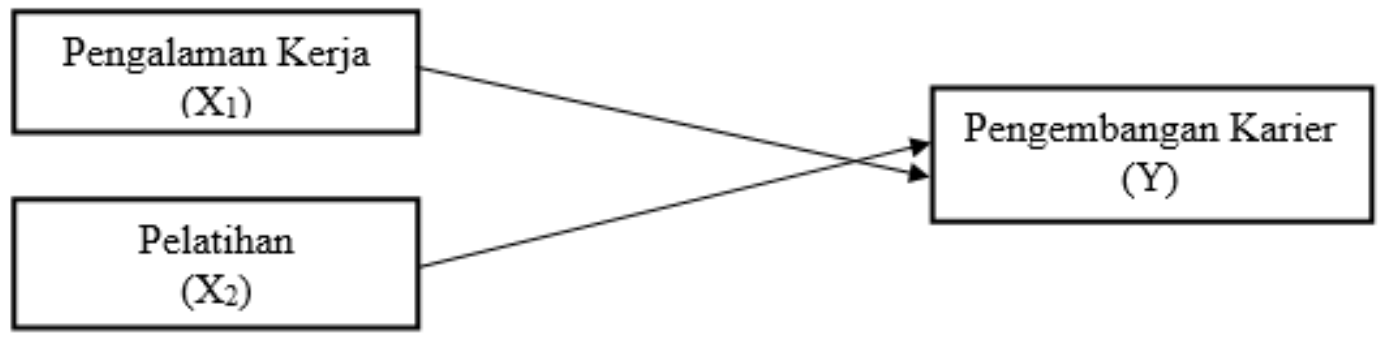

Gambar 1. Kerangka Penelitian 


\section{Hipotesis Penelitian}

Menurut Sugiyono (2014:96) hipotesis merupakan jawaban sementara terhadap rumusan masalah penelitian, dimana rumusan masalah penelitian telah dinyatakan dalam bentuk pertanyaan. Hipoteis juga dapat dinyatakan sebagai jawaban teoritis rumusan masalah penelitian belum jawaban yang empiris. Adapun yang menjadi hipotesis dalam penelitian ini adalah sebagai berikut:

$\mathrm{H}_{\mathrm{a} 1}$ : Diduga pengalaman kerja dan pelatihan berpengaruh terhadap pengembangan karier personil Polri pada Satuan Kerja Biro Operasi Polda Aceh.

$\mathrm{H}_{\mathrm{a} 2}$ : $\quad$ Diduga pengalaman kerja berpengaruh terhadap pengembangan karier personil Polri pada Satuan Kerja Biro Operasi Polda Aceh.

$\mathrm{H}_{\mathrm{a} 3}$ : Diduga pelatihan berpengaruh terhadap pengembangan karier personil Polri pada Satuan Kerja Biro Operasi Polda Aceh

\section{Lokasi dan Objek Penelitian}

Penelitian ini dilakukan pada Satuan Kerja Biro Operasi Polda Aceh, yang beralamat di Jl. Cut Meutia No 25 Banda Aceh. Subjek penelitian ini adalah para seluruh personil Polri pada Satuan Kerja Biro Operasi Polda Aceh. Adapun objek penelitian ini analisis faktor-faktor yang mempengaruhi pengembangan karier personil Polri pada Satuan Kerja Biro Operasi Polda Aceh.

\section{Populasi dan Sampel}

Menurut Sugiyono (2014:115) populasi adalah wilayah generalisasi yang terdiri atas objek atau subjek yang mempunyai karakteristik tertentu yang ditetapkan oleh peneliti untuk dipelajari dan kemudian ditarik kesimpulannya. Sedangkan sampel adalah bagian dari jumlah dan karakteristik yang dimiliki oleh populasi tersebut (Sugiyono, 2014:116). Populasi dalam penelitian ini adalah seluruh personil Polri pada Satuan Kerja Biro Operasi Polda Aceh sebanyak 64 orang personil Polri. Teknik pengambilan sampel dilakukan dengan metode sensus sehingga sampel dalam penelitian ini 64 orang personil Polri pada Satuan Kerja Biro Operasi Polda Aceh. Menurut Sugiyono (2014:78) sensus adalah teknik penentuan sampel bila semua anggota populasi digunakan sebagai sampel.

\section{Data dan Teknik Pengumpulan Data}

Teknik pengumpulan data yang digunakan dalam penelitian ini adalah sebagai berikut:

1. Penelitian Lapangan (field research)

Teknik pengumpulan data yang digunakan untuk memperoleh data yaitu dengan menggunakan wawancara dan kuesioner, yaitu:

a. Wawancara (Interview)

Penulis memperoleh data dengan cara melakukan tanya jawab secara langsung dengan pegawai untuk meminta keterangan mengenai hal yang berhubungan dengan masalah yang diteliti.

b. Angket (Kuesioner)

Dalam penelitian ini metode yang digunakan untuk memperoleh informasi dari responden adalah berbentuk kuesioner.

2. Penelitian kepustakaan (Library Research)

Penelitian kepustakaan dilakukan pada Satuan Kerja Biro Operasi Polda Aceh atau melalui pembelajaran buku-buku, jurnal-jurnal dan penelitian-penelitian atau skripsi yang telah ada sebelumnya yang terkait dengan masalah yang diteliti.

\section{Skala Pengukuran}

Skala pengukuran data yang digunakan adalah Likert (Likert Scale). Skala likert digunakan untuk memberikan skor atau bobot untuk masing-masing alternatif jawaban sehubungan dengan pernyataan/pertanyaan yang dibuat. Menurut Sugiyono (2014:132) skala likert digunakan untuk mengukur sikap, pendapat dan persepsi seseorang atau sekelompok orang tentang fenomena sosial. Biasanya format skala likert merupakan perpaduan antara kesetujuan dan ketidaksetujuan, seperti terlihat dalam Tabel dibawah : 
Tabel 1. Skala Pengukuran

\begin{tabular}{|c|l|c|}
\hline No & \multicolumn{1}{|c|}{ Keterangan (pilihan) } & Skala \\
\hline 1 & Sangat Tidak Setuju & 1 \\
\hline 2 & Tidak Setuju & 2 \\
\hline 3 & Kurang Setuju & 3 \\
\hline 4 & Setuju & 4 \\
\hline 5 & Sangat Setuju & 5 \\
\hline
\end{tabular}

\section{Peralatan Analisis Data}

Menurut Sugiyono (2014:277) analisis regresi linear berganda digunakan untuk menaksir bagaimana keadaan (naik turunnya) variabel dependen, bila dua atau lebih variabel dependen sebagai faktor predictor dimanipulasi (dinaik turunkan nilainya). Menurut Sugiyono (2014:277) bentuk persamaan dari regresi linier berganda adalah sebagai berikut::

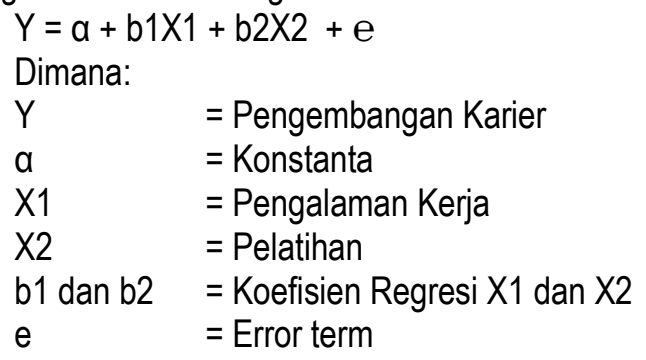

\section{Uji Validitas dan Uji Reliabilitas}

Uji Validitas

Uji Validitas menyatakan bahwa instrumen yang digunakan untuk mendapatkan data dalam penelitian dapat digunakan atau tidak. Menurut Sugiyono (2014:121) menyatakan bahwa valid berarti instrumen tersebut dapat digunakan untuk mengukur apa yang seharusnya diukur. Valid menunjukan derajat ketepatan antara data sesungguhnya terjadi pada objek dengan data yang dikumpulkan oleh peneliti. Dalam penelitian ini, penentuan validitas dapat dilakukan dengan mencari nilai korelasi skor masing-masing item dengan skor total item untuk setiap variabel. Kemudian nilai rhitung yang diperoleh dari korelasi tersebut dibandingkan dengan nilai rtabel pada tingkat keyakinan 95 persen, apabila nilai rhitung>rtabel item pernyataan dinyatakan valid. Sebaliknya apabila nilai rhitung<rtabel maka item pernyataan tidak valid. Menurut Sugiyono (2014:184) suatu indikator dikatakan valid, apabila $n=64$ dan $a=0,05$, maka rtable $=0,242$ dengan ketentuan hasil rhitung>rtable $(0,242)$ valid dan hasil rhitung<rtable $(0,243)$ tidak valid.

\section{Uji Reliabilitas}

Uji reliabilitas menyatakan bahwa apabila instrumen yang digunakan beberapa kali untuk mengukur objek yang sama akan menghasilkan data yang sama. Menurut Sugiyono (2014:122) reliabilitas adalah derajat konsistensi atau keajengan data dalam interval waktu tertentu. Setiap alat ukur seharusnya memiliki kemampuan untuk memberikan hasil yang konsisten. Untuk melihat reabilitas masing-masing instrument yang digunakan, penulis mengemukakan koefisien cornbach's alpha ( ) dengan menggunakan fasilitas SPSS versi 20 . Suatu suatu instrument dikatakan reliabel jika nilai cornbach's alpha ( ) lebih besar dari 0,6.

\section{HASIL PENELITIAN DAN PEMBAHASAN}

\section{Hasil Pengujian Instrumen}

Pengujian Validitas

Uji Validitas menyatakan bahwa instrumen yang digunakan untuk mendapatkan data dalam penelitian dapat digunakan atau tidak. Menurut Sugiyono (2014:184) suatu indikator dikatakan valid, apabila $n=64$ dan $\alpha=$ 0,05 , maka rtable $=0,242$ dengan ketentuan hasil rhitung $>$ rtable $(0,242)$ valid dan hasil rhitung<rtable $(0,243)$ tidak valid. Untuk lebih jelasnya mengenai hasil pengujian validitas dapat dilihat pada Tabel dibawah: 
Tabel 2. Hasil Uji Validitas

\begin{tabular}{|c|c|c|c|c|c|}
\hline No & Variabel & Butir & Nilai Rhitung & $\begin{array}{l}\begin{array}{l}\text { Nilai Rtabel } \\
(\mathrm{N}=64)\end{array}\end{array}$ & Keterangan \\
\hline \multirow[t]{5}{*}{1} & \multirow{5}{*}{$\begin{array}{c}\text { Pengembangan Karir } \\
(\mathrm{Y})\end{array}$} & A1 & 0,376 & 0,242 & Valid \\
\hline & & $\mathrm{A} 2$ & 0,731 & 0,242 & Valid \\
\hline & & A3 & 0,627 & 0,242 & Valid \\
\hline & & A4 & 0,385 & 0,242 & Valid \\
\hline & & A5 & 0,631 & 0,242 & Valid \\
\hline \multirow[t]{5}{*}{2} & \multirow{5}{*}{$\begin{array}{l}\text { Pengalaman Kerja } \\
\left(\mathrm{X}_{1}\right)\end{array}$} & B1 & 0,438 & 0,242 & Valid \\
\hline & & B2 & 0,512 & 0,242 & Valid \\
\hline & & B3 & 0,680 & 0,242 & Valid \\
\hline & & B4 & 0,721 & 0,242 & Valid \\
\hline & & B5 & 0,321 & 0,242 & Valid \\
\hline \multirow[t]{5}{*}{3} & \multirow{5}{*}{$\begin{array}{l}\text { Pelatihan } \\
\left(\mathrm{X}_{2}\right)\end{array}$} & C1 & 0,715 & 0,242 & Valid \\
\hline & & $\mathrm{C} 2$ & 0,339 & 0,242 & Valid \\
\hline & & C3 & 0,814 & 0,242 & Valid \\
\hline & & C4 & 0,567 & 0,242 & Valid \\
\hline & & C5 & 0,851 & 0,242 & Valid \\
\hline
\end{tabular}

Sumber : Data Primer, 2019 (diolah)

Berdasarkan diatas, maka hasil pengujian vadilitas pada setiap variabel mempunyai nilai yang paling rendah, yaitu:.

1. Hasil pengujian validitas untuk variabel pengembangan karir yang terdiri dari 5 (lima) item pernyataan dilambangkan dengan kode item A1, A2, A3 hingga A5 menunjukkan rhitung terendah sebesar 0,376 lebih besar bila dari nilai rtabel $(n=64)$ sebesar 0,242 . Dengan demikian dapat diartikan seluruh item pernyataan yang berhubungan dengan variabel pengembangan karir dinyatakan valid.

2. Hasil pengujian validitas untuk variabel pengalaman kerja yang terdiri dari 5 (lima) item pernyataan dilambangkan dengan kode item B1, B2, B3 hingga B5, menunjukkan nilai rhitung terendah sebesar 0,321 lebih besar dari nilai rtabel $(n=64)$ sebesar 0,242 , sehingga seluruh item pernyataan yang berhubungan dengan variabel pengalaman kerja dinyatakan valid.

3. Hasil pengujian validitas untuk variabel pelatihan yang terdiri dari 5 (lima) item pernyataan dilambangkan dengan kode item C1, C2, C3 hingga C5 menunjukkan nilai rhitung terendah sebesar 0,339 lebih besar dari nilai rtabel $(n=64)$ sebesar 0,242 , maka seluruh item pernyataan yang berhubungan dengan variabel pelatihan dinyatakan valid.

Berdasarkan uraian diatas jelaslah bahwa seluruh item pernyataan yang terdapat pada masing-masing variabel dependen yaitu pengembangan karir dan variabel independen pengalaman kerja dan pelatihan dinyatakan valid, yang berarti kuesioner yang digunakan untuk pengumpulan data dapat digunakan untuk mengukur apa yang seharusnya diukur.

\section{Pengujian Reliabilitas}

Uji reliabilitas menyatakan bahwa apabila instrumen yang digunakan beberapa kali untuk mengukur objek yang sama akan menghasilkan data yang sama. Untuk pengujian penelitian ini menggunakan perhitungan reabilitas dengan statistik cronbach alpha sebesar $>0,60$, itu menunjukan bahwa pengukuran yang dipakai benar dengan mengukur apa yang hendak diukur. Untuk lebih jelasnya dapat dilihat pada Tabel dibawah.

Tabel 3. Hasil Uji Reliabilitas

\begin{tabular}{|c|l|c|c|c|}
\hline No & \multicolumn{1}{|c|}{ Variabel } & $\begin{array}{c}\text { Jumlah } \\
\text { Item }\end{array}$ & $\begin{array}{c}\text { Nilai } \\
\text { Cronbach Alpha }\end{array}$ & Keterangan \\
\hline 1 & Pengembangan Karir $(\mathrm{Y})$ & 5 & 0,704 & Handal \\
\hline 2 & Pengalaman Kerja $\left(\mathrm{X}_{1}\right)$ & 5 & 0,683 & Handal \\
\hline 3 & Pelatihan $\left(\mathrm{X}_{2}\right)$ & 5 & 0,745 & Handal \\
\hline
\end{tabular}

Sumber: Data Primer (Diolah). 
Berdasarkan Tabel 3 dapat diketahui bahwa nilai cronbach alpha untuk beberapa variabel yaitu variabel pengembangan karir $(Y)$ diperoleh nilai cronbach alpha sebesar 0,704 , variabel pengalaman kerja $(\mathrm{X} 1)$ diperoleh nilai cronbach alpha sebesar 0,683 , dan variabel pelatihan (X2) diperoleh nilai cronbach alpha sebesar 0,745 , maka pengukuran reliabilitas memenuhi kredibilitas Cronbach Alpha dimana nilai cronbach alpha >0,60.

\section{Hasil Uji Asumsi Klasik}

Pengujian Normalitas

Uji normalitas data digunakan untuk melakukan pengujian adata observasi apakah data tersebut berdistribusi normal atau tidak. Pada dasarnya, uji normalitas adalah membandingkan antara data yang kita miliki dan data berdistribusi normal yang memiliki mean dan standar deviasi yang sama dengan data kita. Pada prinsipnya normalitas dapat dideteksi dengan melihat penyebaran data (titik) pada sumbu diagonal dari grafik, seperti terlihat dalam Gambar dibawah :

\section{Normal P.P Plot of Regression Standardized Residual}

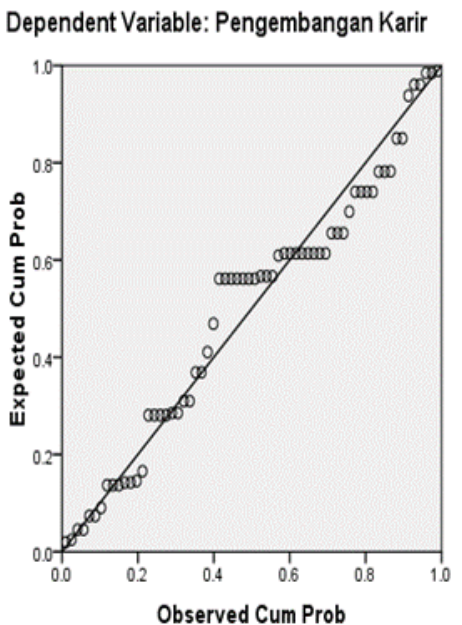

Gambar 2. Normal Probability Plot Hasil Pengujian Normalitas Data.

Berdasarkan Gambar diatas memperlihatkan bahwa garis yang menggambarkan data sesungguhnya menyebar disekitar garis diagonal dan mengikuti arah garis diagonal menunjukkan pola distribusi normal, maka dapat disimpulkan bahwa model regresi memenuhi asumsi normalitas.

\section{Pengujian Multikolinearitas}

Uji multikolinearitas bertujuan untuk menguji apakah dalam model regresi ditemukan adanya korelasi yang tinggi atau sempurna antar variabel independen. Model regresi yang baik seharusnya tidak terjadi korelasi antarvariabel independen. Cara untuk mengetahui ada atau tidaknya gejala multikolinieritas antara lain dengan melihat nilai Variance Inflation Factor (VIF) sebesar $\leq 10$ atau tolerance value sebesaar $\geq 0,10$. Multikolinearitas tidak terjadi bila nilai VIF dibawah nilai 10 atau tolerance value diatas 0,10 , seperti terlihat dalam Tabel dibawah :

Tabel 4. Hasil Pengujian Multikolinieritas

\begin{tabular}{|c|l|c|c|}
\hline No & \multicolumn{1}{|c|}{ Variabel } & Tolerance & VIF \\
\hline 1 & Pengalaman Kerja $\left(X_{1}\right)$ & 0,629 & 1,591 \\
\hline 2 & Pelatihan $\left(X_{2}\right)$ & 0,629 & 1,591 \\
\hline
\end{tabular}

Sumber: Data Primer (Diolah), 2019 
Berdasarkan Tabel 4 dapat dilihat bahwa variabel pengalaman kerja dan pelatihan menunjukkan nilai tolerance sebesar 0,629 0,10 atau sama dengan nilai Variance Inflation Factor (VIF) sebesar 1,591 10 . Dengan demikian dapat diartikan tidak terjadi gejala multikolinieritas.

\section{Pengujian Heteroskedastisitas}

Uji heteroskedastisitas memberikan penjelasan adanya hubungan antara nilai yang diprediksi dengan Studentised Delete Residual masing-masing. Model Regresi layak digunakan untuk memprediksi jika data tersebar berpencar disekitar angka 0 (nol) pada sumbu $Y$ serta tidak membentuk pola atau kecenderungan tertentu, seperti terlihat pada Gambar dibawah.

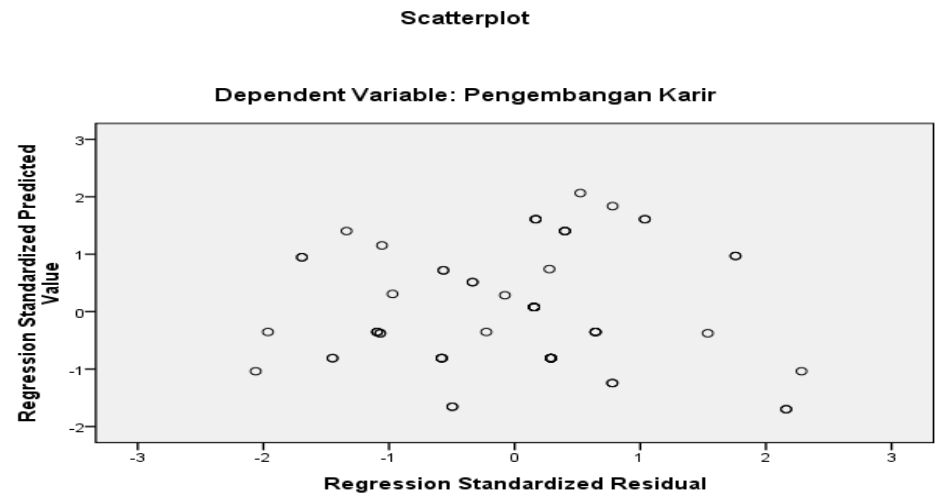

Gambar 3. Grafik Scatterplot Hasil Pengujian Heteroskesdastisitas

Berdasarkan Gambar 4 memperlihatkan bahwa grafik scatterplot tidak memiliki pola tertentu, dan titik-titik menyebar diatas dan dibawah angka 0 pada sumbu Y, maka dapat diartikan tidak terjadi gejala heteroskedastisitas.

\section{Pembahasan}

Berdasarkan hasil penelitian dan pembuktian hipotesis bahwa pengalaman kerja dan pelatihan berpengaruh signifikan terhadap pengembangan karir Personil Polri pada Satuan Kerja Biro Operasi Polda Aceh. Nilai konstanta sebesar sebesar 2,494. Artinya tanpa pengalaman kerja $\left(X_{1}\right)$ dan pelatihan $\left(X_{2}\right)$ dianggap konstan, maka besarnya pengembangan karir Personil Polri pada Satuan Kerja Biro Operasi Polda Aceh adalah sebesar 2,494 pada satuan skala likert.

Hasil koefisien regresi pengalaman kerja $\left(X_{1}\right)$ sebesar 0,272 , artinya bahwa setiap $100 \%$ perubahan dalam pengalaman kerja, maka secara relatif akan mempengaruhi pengembangan karir Personil Polri pada Satuan Kerja Biro Operasi Polda Aceh sebesar $27,2 \%$, maka semakin tinggi pengalaman kerja maka akan mempengaruhi pengembangan karir Personil Polri pada Satuan Kerja Biro Operasi Polda Aceh. Dan hasil koefisien regresi pelatihan $\left(\mathrm{X}_{2}\right)$ sebesar 0,556 , artinya bahwa setiap $100 \%$ perubahan dalam pelatihan, maka secara relatif akan mempengaruhi pengembangan karir Personil Polri pada Satuan Kerja Biro Operasi Polda Aceh sebesar 55,6\%, dengan demikian semakin tinggi pelatihan maka akan semakin mempengaruhi pengembangan karir Personil Polri pada Satuan Kerja Biro Operasi Polda Aceh.

Nilai koefisien korelasi (R) sebesar 0,754 yang menunjukkan bahwa derajat hubungan (korelasi) antara variabel bebas dengan variabel terikat sebesar $75,4 \%$, artinya pengembangan karir Personil Polri pada Satuan Kerja Biro Operasi Polda Aceh mempunyai hubungan yang cukup erat dan positif dengan pengalaman kerja $\left(X_{1}\right)$ dan pelatihan $\left(X_{2}\right)$. Dan nilai korelasi determinasi $\left(R^{2}\right)$ sebesar 0,568 , artinya sebesar $56,8 \%$ perubahan-perubahan dalam variabel terikat yaitu pengembangan karir dapat dijelaskan oleh perubahan-perubahan dalam pengalaman kerja $\left(X_{1}\right)$ dan pelatihan $\left(X_{2}\right)$ dan sisanya sebesar $43,2 \%$ dijelaskan oleh variabel lain diluar dari pada penelitian ini misalnya pendidikan, prestasi kerja, motivasi kerja, disiplin kerja, kompensasi dan lain-lain. Hasil penelitian ini sejalan dengan penelitian yang dilakukan oleh Depri Egota (2015) bahwa pelatihan berpengaruh signifikan terhadap pengembangan karir karyawan sedangkan pengalaman kerja berpengaruh signifikan terhadap pengembangan karir karyawan. Hal ini menunjukkan bahwa pelatihan dan pengalaman kerja pegawai memberikan pengaruh atau dampak positif dan signifikan terhadap peningkatan pengembangan karir pegawai 


\section{KESIMPULAN DAN SARAN}

\section{Kesimpulan}

Berdasarkan hasil penelitian dan pembahasan dapat disimpulkan beberapa hal sebagai berikut:

1. Hasil pengujian statistik uji $F$ menunjukkan bahwa nilai $F_{\text {hitung }}>F_{\text {tabel }}(40,079>3,150)$. Artinya pengalaman kerja $\left(X_{1}\right)$ dan pelatihan $\left(X_{2}\right)$ secara simultan berpengaruh signifikan terhadap pengembangan karir Personil Polri pada Satuan Kerja Biro Operasi Polda Aceh, sehingga hipotesis Ha diterima.

2. Hasil pengujian uji t untuk variabel pengalaman kerja $\left(X_{1}\right)$ menyatakan bahwa nilai $t_{\text {hitung }}>t_{\text {tabel }}(2,562>1,998)$. Artinya pengalaman kerja secara parsial berpengaruh signifikan terhadap pengembangan karir Personil Polri pada Satuan Kerja Biro Operasi Polda Aceh, sehingga hipotesis Ha dapat diterima.

3. Hasil pengujian uji t untuk variabel pelatihan $\left(X_{2}\right)$ menyatakan bahwa nilai $t_{\text {titung }}>t_{\text {tabel }}(5,241>1,998)$. Artinya pelatihan secara parsial berpengaruh signifikan terhadap pengembangan karir Personil Polri pada Satuan Kerja Biro Operasi Polda Aceh, sehingga hipotesis Ha dapat diterima.

4. Nilai koefisien korelasi $(R)$ menunjukkan bahwa derajat hubungan (korelasi) antara variabel bebas dengan variabel terikat sebesar 75,4\%, artinya pengembangan karir Personil Polri pada Satuan Kerja Biro Operasi Polda Aceh mempunyai hubungan yang cukup erat dan positif dengan pengalaman kerja $\left(X_{1}\right)$ dan pelatihan $\left(X_{2}\right)$.

\section{Saran}

Berdasarkan kesimpulan yang diperoleh dari hasil penelitian, adapun saran yang diusulkan adalah:

1. Pada Satuan Kerja Biro Operasi Polda Aceh

a. Pada Satuan Kerja Biro Operasi Polda Aceh perlu meningkatkan pengalaman kerja dan pelatihan terhadap pengembangan karir, pengembangan karir merupakan harapan bagi setiap Personil Polri, karena dengan adanya pengembangan dapat memacu semangat untuk lebih giat dalam bekerja. Pengembangan tidak akan berjalan tanpa adanya kebijakan langsung yang dilakukan oleh Satuan Kerja Biro Operasi Polda Aceh itu sendiri.

b. Perbaikan terhadap kebijkan-kebijakan yang dilakuakan tidaklah akan membawa dampak negatif bagi instansi, karena dengan Personil Polri yang merasa mendapatkan haknya seperti pengembangan karir akan membawa dampak yang positif bagi Satuan Kerja Biro Operasi Polda Aceh. Personil Polri yang merasa nyaman dengan kebijakan-kebijakan yang dilakukan Satuan Kerja Biro Operasi Polda Aceh akan terpacu semangatnya dalam bekerja dan lebih loyal lagi terhadapa instansi. Dengan demikian tidak ada yang akan dirugikan dengan mempertimbangakan perbaikan-perbaikan tersebut.

\section{REFERENSI}

[1] Djauzak, Ahmadi. 2007. Peningkatan Mutu Pendidikan Sebagai Sarana Pembangunan Bangsa. Balai Pustaka: Jakarta.

[2] Dessler, Garry. 2010. Manajemen Sumber Daya Manusia. Edisi Kesepuluh Jilid 1. Penerbit Indeks: Jakarta.

[3] Egota, Depri. 2015. Analisis Faktor-Faktor Yang Mempengaruhi Pengembangan Karir Karyawan Pada PT. Bank Negara Indoneesia (Persero) Tbk Cabang Pekanbaru. Jurnal. Universitas Riau: Riau.

[4] Foster. Bill. 2009. Pembinaan Untuk Peningkatan Kinerja Karyawan. PPM: Jakarta.

[5] Handoko, T. Hani. 2008. Manajemen Personalia dan Sumber Daya Manusia. BPFE: Yokyakarta.

[6] Hardjana, d, Agus, M. 2007. Komunikasi Intrapersonal dan Interpersonal. Yogyakarta: Kanisuis.

[7] Hasibuan, Melayu S.P. 2013. Manajemen Sumber Daya Manusia. Edisi Revisi. Bumi Aksara: Jakarta.

[8] Ismanto, Nano. 2008. Pengaruh Pengalaman Kerja dan Disiplin Kerja Terhadap

[9] Mangkunegara, A Anwar Prabu. 2011. Manajemen Sumber Daya Manusia. Remaja Kosda Karya: Bandung.

[10] Mangkuprawira, Sjafri. 2008. Manajemen Sumber Daya Manusia Strategik. Jakarta: Ghalia Indonesia

[11] Marwansyah Dan Mukaram. 2010. Manajemen Sumber Daya Manusia. Penerbit Administrasi Niaga: Bandung. 
[12] Mathis, Robert R. \& John H. Jackson. 2009. Manajemen Sumber Daya Manusia. Penerbit Salemba Empat: Jakarta.

[13] Muslem. 2015. Faktor-Faktor Yang Mempengaruhi Pengembangan Karir Pegawai Kantor Baitul Mal Aceh. Skripsi. Universitas Serambi Mekkah: Banda Aceh.

[14] Raymond A, et al. 2010. Manajemen Sumber Daya Manusia. Penerbit Indeks: Jakarta.

[15] Rivai, Veithzal. 2009. Manajemen Sumber Daya Manusia Untuk Perusahaan. Rajagrafindo Persada: Jakarta.

[16] Rivai, Veithzal dan Sagala, Ella J. 2009. Manajemen Sumber Daya Manusia Untuk Perusahaan. Penerbit Raja Grafindo Persada: Jakarta.

[17] Samsudin, Sadili. 2008. Manajemen Sumber Daya Manusia. Cetakan ke-1. CV Pustaka Setia: Bandung.

[18] Sarwono, Jonathan. 2012. Path Analysis Dengan SPSS: Teori, Aplikasi, Prosedur Analisis Untuk Riset Skripsi, Tesis Dan Disertasi. Penerbit PT. Elex Media Komputindo: Jakarta.

[19] Sarwono, Jonathan dan Herlina Budiono. 2012. Aplikasi untuk Riset Skripsi, Tesis dan Disertasi Menggunakan SPSS, AMOS dan Excel. Penerbit Andi: Jakarta.

[20] Sedarmayanti. 2010. Manajemen Sumber Daya Manusia (Reformasi Birokrasi Manajene PNS. Refika Aditama: Bandung.

[21] Siagian, Sondong. P. 2008. Kiat Meningkatkan Produktivitas Kerja. PT Rineka Cipta: Jakarta.

[22] Simamora. H. 2008. Manajeman Sumber Daya Manusia. Sekolah Tinggi Ilmu Ekonomi. YKPN: Yogyakarta.

[23] Sihotang. 2009. Manajemen Sumber Daya Manusia. Pradnya Paramita: Jakarta.

[24] Soeprihanto, Jhon. 2009. Penilaian Kinerja Dan Pengembangan Karyawan. BPFE: Yogyakarta.

[25] Sugiyono. 2014. Metode Penelitian Kuantitatif, Kualitatif dan R\&D. CV Alfabeta: Bandung.

[26] Sutrisno. 2009. Manajemen Sumber Daya Manusia. Prenada Media Grup: Jakarta.

[27] Suwatno. 2009. Manajemen Sumber Daya Manusia. Alfabeta. Bandung.

[28] Syukur. 2007. Metode Penelitian Dan Penyajian Data Pendidikan. Medya Wiyata: Semarang.

[29] Tohardi, Ahmad. 2007. Pemahaman Praktis Manajemen Sumber Daya Manusia. Universitas Tanjung Pura, Mandar Maju: Bandung.

[30] Trimulyani Subarti. 2010. Analisis Pengaruh Kompetensi Jabatan Dan Pengembangan Karier Terhadap Kinerja Pegawai Pada Rumah Sakit Umum Daerah Kabupaten Subang. Jurnal IImu Sosial. Universitas Pasundan Bandung.

[31] Wahyudi, Dedi. 2016. Pengaruh Penempatan, Pengalaman Dan Lingkungan Kerja Terhadap Loyalitas Pegawai Pada Kantor Dinas Pendidikan Provinsi Aceh. Skripsi. Universitas Serambi Mekkah: Banda Aceh.

[32] Yani M. 2012. Manajemen Sumber Daya Manusia. Mitra Wacana Media: Jakarta. 